\title{
Comments on 'Comparison of anticoagulation strategies for veno-venous ECMO support in acute respiratory failure': the bitter truth about unfractionated heparin monitoring assays
}

\author{
Mouhamed Djahoum Moussa ${ }^{1,4^{*}} \mathbb{0}$, Osama Abou-Arab ${ }^{1,2}$, Emmanuel Robin $^{1}$ and André Vincentelli ${ }^{3}$
}

To the editor,

We read with interest the article by Benjamin Seeliger et al. [1] in which the authors compared two different anticoagulation strategies defined as high-dose (HD) heparinization and low-dose (LD) heparinization. They report a lower rate of ECMO oxygenator change and thromboembolic events, in the HD group as compared to LD group.

1. The limits of activated clotting time (ACT) and partial thromboplastin time (PTT) to monitor ECMO anticoagulation.

LD and HD heparinization were defined using different anticoagulation monitoring assays-PTT and ACT respectively-leading to a possible classification bias. These assays are known to be poorly correlated to heparin concentration, to heparin anti-FXa and to each other [2].

This comment refers to the article available online at https://doi.org/10.1186/ s13054-020-03348-w.

${ }^{*}$ Correspondence: mouhamed.moussa@chru-lille.fr

${ }^{4}$ Service d'Anesthésie-Réanimation Cardiovasculaire et Thoracique, Institut Cœur - Poumon, CHU Lille, 2 avenue Oscar Lambret, 59037 Lille, France

Full list of author information is available at the end of the article
Notably, the mean PTT values in the HD and LD groups [48 s (IQR 41-57) vs 38 s (IQR 34-42)] were overlapped for $25 \%$ of patients despite a significant difference in heparin dose. This underlines the poor correlation between heparin concentration and the monitoring assays used. Moreover, the difference in mean PTT is uninterpretable without providing for each PTT assay, the heparin therapeutic range is corresponding to the anti-FXa range of $0.3-0.7 \mathrm{UI} / \mathrm{ml}[3]$.

Furthermore, the accuracy of PTT and even worse of ACT are sensitive to several analytical limitations, and biological factors (thrombocytopenia, coagulation factor deficiencies, etc.) unrelated to heparin therapy are commonly observed during ECMO support [2, 4].

In addition, the ELSO recommends that ACT or PTT should not be used in isolation for heparin monitoring due to their limitations [5].

2. The observed differences in thrombotic events cannot be explained by the difference in heparin dosage alone.

The transfusion strategies in both centers differed significantly and should not be ignored in the analyses. Patients in the LD heparinization group received more platelet concentrates and more prothrombin complex concentrates, in line with the liberal transfusion practices in this original author(s) and the source, provide a link to the Creative Commons licence, and indicate if changes were made. The images or other third party material in this article are included in the article's Creative Commons licence, unless indicated otherwise in a credit line to the material. If material is not included in the article's Creative Commons licence and your intended use is not permitted by statutory regulation or exceeds the permitted use, you will need to obtain permission directly from the copyright holder. To view a copy of this licence, visit http://creativecommons.org/licenses/by/4.0/. The Creative Commons Public Domain Dedication waiver (http://creativeco mmons.org/publicdomain/zero/1.0/) applies to the data made available in this article, unless otherwise stated in a credit line to the data. 
center. However, these confounders were not included in the multivariate analysis.

Since the baseline coagulation covariates (fibrinogen, $\mathrm{d}$-dimers, antithrombin) included in the model are likely to fluctuate daily during ECMO, they should be analyzed as time-varying covariates in the multivariate model. ACT and PTT may have similar variations, so it would be more informative to analyse them as time-dependent covariates in a multivariate model to explain thrombotic and bleeding complications.

In conclusion, this study has compared the ECMO management procedures of two centers beyond heparinization alone, in two different populations with a methodology that may lead to misinterpretation.

\section{Authors' response}

Benjamin Seeliger ${ }^{5}$, Andreas Tiede ${ }^{6}$, Sascha David ${ }^{7}$, Christian Bode $^{8^{*}}$

*Correspondence: Christian.bode@ukbonn.de

${ }^{5}$ Department of Respiratory Medicine, Hannover Medical School and German Centre for Lung Research (DZL), Hannover, Germany.

${ }^{6}$ Department of Haematology, Haemostasis, Oncology, and Stem Cell Transplantation, Hannover Medical School, Hannover, Germany.

${ }^{7}$ Institute of Intensive Care Medicine, University Hospital Zurich, Zurich, Switzerland.

${ }^{8}$ Department of Anaesthesiology and Intensive Care Medicine, University Hospital Bonn, Bonn, Germany.

\section{To the editor,}

We thank Moussa et al. for their comments on our article, addressing the issue of heparin monitoring and potential confounders.

Concerning the monitoring of heparin, we agree that APTT and ACT poorly correlate with each other and with anti-Xa levels in critically ill patients. Our own group recently confirmed this observation using two modern ACT devices with different detection methods [6]. As outlined in the current paper, we employed additional anti-Xa measurements whenever APTT or ACT was inconsistent with heparin dose or clinical picture. The main study result was a significant difference in heparin dose $(17,495 \mathrm{vs} 11,185 \mathrm{IU} / \mathrm{d}, p<0.001)$ and a remarkable difference in the risk of oxygenator change between the two centers.

An intriguing question is why most centers, despite ELSO recommendations and the well-known limitations of APTT/ACT, still use these assays in the majority of patients [7]. Is it ignorance and lethargy that anti-Xa assays have not been adopted more completely? Or is it their longer turnaround time, higher cost and lack of $24 / 7$ availability? It must be acknowledged that anti-Xa assays do not measure heparin concentration but just one of its pharmacodynamic, antithrombin-dependent effects. Different anti-Xa assays (with or without addition of exogenous antithrombin) do not measure the same in critically ill patients with low antithrombin [8]. Neither do anti-Xa assays reflect the important effects heparin has on other coagulation enzymes and the expression of tissue factor and tissue factor pathway inhibitor [9]. Proof is lacking that anti-Xa monitoring improves the outcome of ECMO patients. So-called global hemostasis assays may possibly better reflect the complex alterations of hemostasis and guide the use of heparin and blood components [10].

Concerning the transfusion strategy as a potential confounder, we agree with Moussa et al. and concluded already in our paper that prospective studies with predefined transfusion strategies are needed. We do not agree that transfusions could have been simply included as covariates in our analysis. The dilemma is that transfusion, for example, of platelets, may potentially prevent bleeding but is also done because of already existing bleeding.

In conclusion, our retrospective comparison of realworld data from two centers found lower rates of oxygenator change and thromboembolic complications in the center employing higher doses of heparin. Patient baseline characteristics were unlikely to explain this difference. Because of other potential confounders (e.g. transfusion strategy), confirmation from prospective studies is required.

\section{Abbreviations \\ Anti-FXa: Antifactor Xa; ECMO: Extracorporeal membrane oxygenation; ELSO: Extracorporeal life support organization; IQR: Interquartile range.}

\section{Acknowledgements}

We are grateful to Jocelyn Dumontet for his help for language editing. AV is a member of the French Working Group on Perioperative Hemostasis (GIHP, Groupe d'Intérêt en Hémostase Périopératoire).

Author details

AV is a member of the French Working Group on Perioperative Hemostasis (GIHP, Groupe d'Intérêt en Hémostase Périopératoire).

\section{Authors' contributions}

MDM and OAA write the manuscript; ER and AV performed critical review of the manuscript. All authors read and approved the final manuscript.

\section{Funding}

Not applicable.

\section{Availability of data and materials} Not applicable.

\section{Declarations}

Ethics approval and consent to participate Not applicable.

Consent for publication

Not applicable. 


\section{Competing interests}

All authors declare no conflicting interest.

\section{Author details}

${ }^{1}$ CHU Lille, Pôle d'Anesthésie-Réanimation, F-59000 Lille, France. ${ }^{2}$ Department of Anesthesiology and Critical Care Medicine, Amiens University Hospital, Amiens, France. ${ }^{3}$ CHU Lille, Service de Chirurgie Cardiaque, F-59000 Lille, France. ${ }^{4}$ Service d'Anesthésie-Réanimation Cardiovasculaire et Thoracique, Institut Cœur - Poumon, CHU Lille, 2 avenue Oscar Lambret, 59037 Lille, France.

Received: 9 February 2021 Accepted: 2 March 2021

Published online: 29 March 2021

\section{References}

1. Seeliger B, Döbler M, Friedrich R, Stahl K, Kühn C, Bauersachs J, et al. Comparison of anticoagulation strategies for veno-venous ECMO support in acute respiratory failure. Crit Care. 2021;24:701.

2. Chlebowski MM, Baltagi S, Carlson M, Levy JH, Spinella PC. Clinical controversies in anticoagulation monitoring and antithrombin supplementation for ECMO. Crit Care. BioMed Central; 2020;24. https://www.ncbi.nlm. nih.gov/pmc/articles/PMC6971875/Cited 10 Feb 2021

3. Marlar RA, Clinical and Laboratory Standards Institute. One-stage prothrombin time (PT) test and activated partial thromboplastin time (APTT) test: approved guideline. Wayne, PA: Clinical and Laboratory Standards Institute; 2008.

4. Abbasi A, Karasu Y, Li C, Sodha NR, Eickhoff C, Ventetuolo CE. Machine learning to predict hemorrhage and thrombosis during extracorporeal membrane oxygenation. Crit Care. 2020;24. https://www.ncbi.nlm.nih. gov/pmc/articles/PMC7727105/. Cited 10 Feb 2021.

5. elsoanticoagulationguideline8-2014-table-contents.pdf. https://www elso.org/Portals/0/Files/elsoanticoagulationguideline8-2014-table-conte nts.pdf. Cited 22 Jan 2021.

6. Wehner JE, Boehne M, David S, Brand K, Tiede A, Bikker R. Activated clotting time (ACT) for monitoring of low-dose heparin: performance characteristics in healthy adults and critically ill patients. Clin Appl Thromb Hemost. 2020;26:1076029620975494. https://doi.org/10.1177/ 1076029620975494

7. Esper SA, Welsby IJ, Subramaniam K, John Wallisch W, Levy JH, Waters $\mathrm{JH}$, et al. Adult extracorporeal membrane oxygenation: an international survey of transfusion and anticoagulation techniques. Vox Sang. 2017;112:443-52. https://doi.org/10.1111/vox.12514

8. Ranucci M, Cotza M, Isgrò G, Carboni G, Ballotta A, Baryshnikova E. Anti-factor Xa-based anticoagulation during extracorporeal membrane oxygenation: potential problems and possible solutions. Semin Thromb Hemost. 2020:46:419-27. https://doi.org/10.1055/s-0039-1697950.

9. Vignoli A, Marchetti M, Balducci D, Barbui T, Falanga A. Differential effect of the low-molecular-weight heparin, dalteparin, and unfractionated heparin on microvascular endothelial cell hemostatic properties. Haematologica. 2006:91:207-14

10. Schmidt AE, Israel AK, Refaai MA. The utility of thromboelastography to guide blood product transfusion. Am J Clin Pathol. 2019;152:407-22. https://doi.org/10.1093/ajcp/aqz074.

\section{Publisher's Note}

Springer Nature remains neutral with regard to jurisdictional claims in published maps and institutional affiliations.
Ready to submit your research? Choose BMC and benefit from:

- fast, convenient online submission

- thorough peer review by experienced researchers in your field

- rapid publication on acceptance

- support for research data, including large and complex data types

- gold Open Access which fosters wider collaboration and increased citations

- maximum visibility for your research: over $100 \mathrm{M}$ website views per year

At BMC, research is always in progress.

Learn more biomedcentral.com/submissions 